\title{
Uji Daya Hasil 10 Galur Cabai Rawit ( Capsicum annuum L. ) IPB di Kecamatan Dramaga, Bogor
}

\section{Yield Evaluation of 10 Chili Pepper (Capsicum annuum L.) Lines in Dramaga, Bogor}

\author{
Dwika Syattwa Arandito1, Muhamad Syukur ${ }^{1,2^{*}}$, Arya Widura Ritonga ${ }^{1,2}$
}

\begin{abstract}
${ }^{1}$ Departemen Agronomi dan Hortikultura, Fakultas Pertanian, Institut Pertanian Bogor (Bogor Agricultural University), Jalan Meranti, Kampus IPB Darmaga, Bogor 16680, Indonesia.

${ }^{2}$ Pusat Kajian Hortikultura Tropika, Lembaga Penelitian dan Pengabdian kepada Masyarakat Institut Pertanian Bogor, Jl. Raya Pajajaran, Kampus IPB Baranangsiang, Bogor, Indonesia
\end{abstract}

Diterima 28 September 2018/Disetujui 22 Oktober 2018

\begin{abstract}
Chili is an important vegetable commodity in Indonesia. Chilli can be used for cooking ingredients and used as a basic ingredient in the food industry. This study aims to evaluate some quantitative characters and qualitative characters as an indicator of yield as a reference for obtaining lines that can be nominated into new varieties. Research was been carried out from February to July 2018 at the Leuwikopo Experimental Garden, IPB. The height of the research site was $\pm 197 \mathrm{~m}$ above sea level. The design used in this study was Randomized Complete Block Design with a single factor, namely genotype. The number of genotypes that being used consists of 10 test genotypes, and 5 comparison varieties with 3 repetitions. Thus, there was total 45 experimental units. The research outcome was that the lines tested showed significant effect and had differences between the ten test lines except for the flowering age character. Lines F8160291-9-4-3-2-1-1 and F6145291115-8-1-1 were lines that had better plant growth characteristics. The fruit characteristics of the lines F8160291-3-12-5-451-1 and F6145291-14-9-3-12 had good fruit weight and fruit length compared to all comparison varieties. Based on the correlation analysis, the character of the number of fruit and weight of fruit were very important to determine the performance of the plant. Line F8160291-3-12-5-4-51-1 and F6145291-14-9-3-12, F8160291-9-4-3-2-1-1, and F6145291-115-8-1-1 had potential character to be released as new varieties.
\end{abstract}

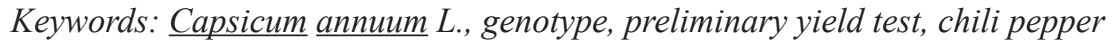

\section{ABSTRAK}

Cabai termasuk kedalam komoditas sayuran penting di Indonesia. Buah cabai dapat digunakan untuk bumbu masakan dan dimanfaatkan sebagai bahan dasar industri pangan. Penelitian ini bertujuan melakukan evaluasi karakter kuantitatif sebagai indikator daya hasil dan karakter kualitatif untuk mendapatkan galur-galur yang dapat dicalonkan menjadi varietas unggul baru. Penelitian dilaksanakan dari bulan Januari hingga Juli 2018 di Kebun Percobaan Leuwikopo dan Laboratorium Genetika dan Pemuliaan Tanaman, Departemen Agronomi dan Hortikultura, Fakultas Pertanian IPB. Ketinggian tempat penelitian yaitu $\pm 197 \mathrm{~m}$ dpl. Rancangan yang digunakan dalam penelitian ini adalah Rancangan Kelompok Lengkap Teracak faktor tunggal yaitu genotipe. Jumlah genotipe yang digunakan terdiri atas 10 genotipe uji dan 5 varietas pembanding yang diulang sebanyak 3 ulangan sehingga terdapat 45 satuan percobaan. Hasil penelitian menunjukan bahwa galur-galur uji cabai rawit memiliki pengaruh yang nyata terhadap seluruh karakter kuantitatif kecuali umur berbunga. Galur F8160291-9-4-3-2-1-1 dan F6145291-115-8-1-1 merupakan galur yang memiliki nilai karakter vegetatif tanaman lebih tinggi dibandingkan varietas pembanding. Karakter buah pada galur F8160291-3-12-5-4-51-1 dan F6145291-14-93-12 memiliki nilai yang tinggi dibandingkan dengan seluruh varietas pembanding. Berdasarkan analisis kolerasi, karakter jumlah buah dan bobot per buah memiliki korelasi nyata dan positif terhadap bobot per tanaman. Galur F8160291-3-12-54-51-1 dan F6145291-14-9-3-12, F8160291-9-4-3-2-1-1, dan F6145291-115-8-1-1 memiliki potensi untuk dilepas sebagai calon varietas baru.

Kata kunci : Capsicum annuum L., genotipe cabai,uji pendahuluan, cabai rawit

\footnotetext{
* Penulis untuk korespondensi. e-mail: muhsyukur@ipb.ac.id
} 


\section{PENDAHULUAN}

Cabai (Capsicum annuum L.) merupakan salah satu komoditas tanaman hortikultura dari famili Solanaceae yang tidak hanya bernilai ekonomi tinggi, tetapi juga buahnya memiliki kombinasi warna, rasa, dan nutrisi yang lengkap (Kouassi et al., 2012). Tanaman cabai menjadi komoditas sayuran terpenting di Indonesia. Luas areal penanaman cabai pada tahun 2015 merupakan yang terbesar di antara komoditas sayuran lainnya dengan luasan mencapai 254 ribu hektar (BPS, 2016). Berperan sebagai bahan makanan, tanaman cabai merupakan komponen bahan makanan yang penting. Hal ini dikarenakan masyarakat Indonesia setiap hari menggunakan cabai sebagai salah satu bahan makanan di setiap masakan (Tsurayya dan Kartika, 2015). Peningkatan penggunaan cabai sebagai bahan makanan sebesar $10.87 \%$ terjadi setiap tahun dan total penggunaan cabai sebagai bahan makanan sebesar 1.925 juta ton di tahun 2014 (Kementan, 2016). Kondisi permintaan cabai yang tinggi tidak mampu diimbangi dengan baik oleh produksi nasional sehingga terdapat kekurangan sebesar 49,925 ton cabai di tahun 2014 (Kementan, 2016). Kondisi ini mampu mempengaruhi kondisi ekonomi dalam negeri baik secara langsung ataupun tidak langsung seperti perubahan nilai inflasi.

Tanaman cabai sering kali menjadi penyumbang utama kenaikan inflasi pada kelompok volatile food seperti yang terjadi di bulan September dan Oktober 2016 (Bank Indonesia, 2016). Data yang didapatkan dari Badan Pusat Statistik (2015) dan Dirjen Hortikultura, produktivitas rata rata untuk tanaman cabai rawit baru mencapai 6.45 ton $\mathrm{ha}^{-1}$, masih jauh jika dibandingkan dengan potensinya yang dapat mencapai 10-12 ton ha-1 (Kementan, 2017). Terdapat beberapa upaya untuk meningkatkan produktivitas tanaman cabai rawit. Salah satunya adalah mengupayakan peningkatan produktivitas melalui perakitan varietas baru unggul melalui program pemuliaan tanaman.

Kegiatan pemuliaan tanaman yaitu kegiatan untuk memperbaiki sifat suatu tanaman dari tanaman sebelumnya (Syukur et al., 2015). Tujuan dari pemuliaan tanaman diantaranya perbaikan kuantitas hasil, kualitas hasil, ketahanan pasca panen, ketahanan hama-penyakit dan ketahanan terhadap lingkungan suboptimal atau marginal (Wattimena, 2011). Kegiatan pemuliaan tanaman penting untuk merakit varietas-varietas unggul baru yang berkemampuan lebih baik dalam menghasilkan biomassa serta menyalurkan ke bagian yang dapat di panen (Syukur et al., 2015). Penggunaan varietas unggul pada tanaman merupakan langkah penting untuk menentukan besarnya produksi pada saat panen (Poerwanto dan Susila, 2014).

Proses pemuliaan tanaman diantaranya, seleksi, uji dayahasil pendahuluan, uji daya hasil lanjutan, uji keunggulan dan uji kebenaran varietas, dan pelepasan varietas. Pemuliaan tanaman cabai rawit (Capsicum annuиm L) jenis bersari bebas setelah melalui proses seleksi dilanjutkan dengan uji daya hasil pendahuluan dan lanjutan (Syukur et al., 2015). Pengujian ini dilakukan sebelum dilakukan uji daya adaptasi dan stabilitas calon varietas (Syukur et al., 2015). Tahapan ini penting untuk membentuk galur yang siap dilepas sebagai varietas unggul. Penelitian tentang uji daya hasil ini akan mengevaluasi dan memilih galur potensial dari program Pemuliaan Tanaman Departemen Agronomi dan Hortikultura IPB. Penelitian ini bertujuan untuk mengevaluasi karakter kuantitatif yang mempengaruhi daya hasil sepuluh galur cabai rawit (Capsicum annuum L.) IPB dan 5 varietas komersial sebagai pembanding.

\section{BAHAN DAN METODE}

Penelitian dilaksanakan pada bulan Januari 2018 sampai dengan bulan Juli 2018. Penanaman dan pengamatan dilakukan di Kebun Percobaan IPB, Leuwikopo. Kebun Percobaan IPB Leuwikopo terletak pada ketinggian \pm 197 m dpl. Pengamatan pascapanen dilakukan di Laboratorium Pemuliaan Tanaman, Departemen Agronomi dan Hortikultura, Faperta, IPB.

Bahan tanam yang digunakan dalam penelitian ini terdiri atas sepuluh galur harapan cabai rawit (Capsicum annuumL.) hasil perakitan Divisi Genetika dan Pemuliaan Tanaman IPB dan lima varietas komersil sebagai pembanding.Bahan yang digunakan yaitu media tanam, pupuk NPK mutiara $16: 16: 16\left(10 \mathrm{~g} \mathrm{~L}^{-1}\right)$, pupuk kandang (20 ton ha-1), dan pupuk dasar yaitu Urea $\left(200 \mathrm{~kg} \mathrm{ha}^{-1}\right)$, $\mathrm{KCl}\left(150 \mathrm{~kg} \mathrm{ha}^{-1}\right)$ dan SP36 (150 kg ha $\left.{ }^{-1}\right)$. Pestisida yang digunakan di antaranya tediri atas insektisida berbahan aktif Profenofos $500 \mathrm{~g} \mathrm{~L}^{-1}$, fungisida berbahan aktif Mankozeb $80 \%$. Alat yang digunakan adalah tray semai, gembor, ajir, cangkul, kored, meteran, timbangan analitik, timbangan kasar, sprayer, tali rafia, plastik, label, dan jangka sorong.

Rancangan percobaan yang digunakan adalah Rancangan Kelompok Lengkap Teracak (RKLT) dengan satu faktor yaitu genotype cabai. Bahan tanam yang digunakan yaitu 15 genotipe cabai yang terdiri atas 10 galur harapan dan 5 varietas komersil (Bara, Taringie, Batari, Genie, Catas) sebagai pembanding. Setiap perlakuan genotype dilakukan pengulangan sebanyak 3 kali sehingga total terdapat 45 satuan percobaan. Setiap satuan percobaan terdiri atas 20 tanaman, dengan 10 tanaman digunakan sebagai tanaman contoh sehingga terdapat total 450 tanaman contoh.

Pengamatan dilakukan terhadap peubah kuantitatif 10 tanaman contoh setiap genotipe pada setiapulangan berdasarkan deskriptorcabai (IPGRI 1995) dan Direktorat Perbenihan Hortikultura (2017). Karakter kuantitatif yang diamati yaitu tinggi tanaman $(\mathrm{cm})$, tinggi dikotomus $(\mathrm{cm})$, diameter batang $(\mathrm{cm})$, panjang daun $(\mathrm{cm})$, lebar daun $(\mathrm{cm})$, panjang buah $(\mathrm{cm})$, diameter buah $(\mathrm{cm})$, tebal kulit buah (cm), umur berbunga (HST), umur panen (HST), bobot buah per tanaman $(\mathrm{g})$, bobot per buah (g). Perbedaan karakter kuantitatif antara genotipe yang dievaluasi diuji dengan uji F. Apabila hasil pengujian menunjukan bahwa perlakuan berpengaruh nyata pada taraf $5 \%$ dan atau $1 \%$ maka dilakukan uji lanjut dengan menggunakan DMRT pada taraf 5\%. Analisis karakter dilakukan menggunakan software SAS 9.0 dan Microsoft Excel. Hubungan antar karakter dianalisis menggunakan aplikasi STAR. 


\section{HASIL DAN PEMBAHASAN}

\section{Keragaan Karakter Kuantitatif}

Analisis ragam terhadap sepuluh galur uji cabai rawit IPB menunjukan bahwa genotipe berpengaruh sangat nyata pada karakter tinggi tanaman, tinggi dikotomus, diameter batang, panjang daun, lebar daun, panjang buah, diameter buah, tebal kulit buah, bobot per buah, bobot per tanaman, dan umur panen. Sedangkan genotipe tidak berpengaruh nyata pada karakter umur berbunga (Tabel 1).

Koefisien keragaman yang didapatkan memiliki nilai berkisar antara $1.73 \%$ hingga $20.61 \%$. Gomez dan Gomez (1995) menyatakan bahwa nilai koefisien keragaman menunjukan tingkat akurasi dan merupakan indeks yang baik dari suatu keadaan percobaan. Nilai KK yang semakin rendah menjelaskan bahwa tingkat validasi suatu percobaan semakin tinggi. Karakter dengan nilai koefisien keragaman paling kecil adalah umur panen $(1.73 \%)$ sedangkan nilai koefisien keragaman tertinggi pada karakter bobot buah tinggi yaitu $20.61 \%$ (Tabel 1 ).

Tanaman cabai rawit saat penelitian memiliki tinggi antara 67.43-32.62 cm. Galur yang memiliki karakter paling tinggi adalah F8160291-9-1 sedangkan terendah yaitu F8145381-1-1. Data pada Tabel 3 menunjukan bahwa hanya galur F8160291-9-1 yang nyata lebih tinggi dibandingkan seluruh varietas pembanding. Genotipe F8145291-1158-1-1, dan F6160291-4-13-9-8 memiliki tinggi tanaman sebanding dengan varietas Taringe dan nyata lebih tinggi dibandingkan varietas lainnya. Genotipe F6145291-10-71-1-1, F8160291-3-12-5-4-51-1, dan F6145174-9-7-1-5 memiliki tinggi tanaman yang sebanding dengan varietas

Tabel 1. Rekapitulasi sidik ragam keragaan sepuluh galur uji dan lima varietas pembanding

\begin{tabular}{lcc}
\hline \multicolumn{1}{c}{ Karakter } & KK $(\%)$ & KT \\
\hline Tinggi Tanaman & 8.1 & $14.49^{* *}$ \\
Tinggi Dikotomus & 7.12 & $18.3^{* *}$ \\
Diameter Batang & 7.12 & $8.27^{* *}$ \\
Panjang Daun & 8.36 & $8.07^{* *}$ \\
Lebar Daun & 13.83 & $4.8^{* *}$ \\
Panjang Buah & 13.78 & $5.21^{* *}$ \\
Diameter Buah & 6.36 & $1.45^{* *}$ \\
Tebal Kulit Buah & 14.94 & $3.46^{* *}$ \\
Bobot Per Buah & 18.13 & $5.78^{* *}$ \\
Bobot Per Tanaman & 20.61 & $10.21^{* *}$ \\
Umur Berbunga & 5.65 & $1.26^{\text {th }}$ \\
Umur Panen & 1.73 & $24.3^{* *}$ \\
Jumlah Buah & 20.25 & $10.33^{* *}$ \\
\hline
\end{tabular}

Keterangan: $\mathrm{KK}=$ Koefisien Keragaman, $\mathrm{KT}=$ Kuadrat Tengah, $* *=$ berpengaruh nyata pada taraf $\alpha 1 \%$, tn $=$ tidak berpengaruh nyata pada taraf $\alpha=5 \%$
Bara, Genie, dan Catas. Sifat tinggi dikotomus memiliki nilai pada rentang $30.29-14.40 \mathrm{~cm}$. Tinggi dikotomus terendah dimiliki oleh galur F8145381-1-1 tidak berbeda nyata terhadap seluruh varietas pembanding. Galur F81452 1-115-8-1-1 memiliki nilai tinggi dikotomus paling tinggi. Genotipe F6160291-19-14-1-5 dan F8145291-115-8-1-1 memiliki tinggi dikotomus sebanding dengan varietas Taringe dan nyata lebih tinggi dibandingkan varietas pembanding lainnya (Tabel 2).

Hasil uji lanjut menunjukan galur uji memiliki nilai diameter batang antara 10.52-7.06 cm sedangkan diameter batang varietas pembanding berikisar antara 29.03-20.47 cm. Galur F8160291-9-4-3-2-1-1, F7145291-14-10-10-4-9, dan F8160291-3-12-5-4-51-1 memiliki diameter batang sebanding dengan varietas Taringe dan nyata lebih besar dibandingkan varietas Bara, Genie, Batari, dan Catas. Genotipe F6145291-10-7-1-1-1, F6160291-4-13-9-8, F6145174-9-7-1-5, F6160291-19-14-1-5 memiliki nilai diameter batang nyata lebih besar dibandingkan varietas Batari dan sebanding dengan varietas Bara, Genie, dan Catas (Tabel 3).

Panjang daun pada galur cabai yang diuji berkisar antara 4.81-7.31 cm. Sedangkan varietas pembanding memiliki nilai panjang daun antara 4.77-6.77 $\mathrm{cm}$ (Tabel 2). Galur F7145291-14-10-10-4-9 dan F8145291-115-8-1-1 memiliki nilai panjang daun yang nyata lebih panjang dibandingkan seluruh varietas. Genotipe F6145291-10-7-1-1-1, F81602913-12-5-4-51-1, F6145291-14-9-3-12, F6160291-4-13-9-8, dan F6160291-19-14-1-5 memiliki daun yang nyata lebih panjang dibandingkan varietas pembanding Batari dan sebanding dengan varietas pembanding lainnya. Galur cabai yang diuji memiliki nilai lebar daun antara 1.71-3.17 cm sedangkan daun pada varietas pembanding memiliki lebar berkisar 2.55-3.40 cm (Tabel 2). Galur F7145291-14-10-104-9, F6160291-4-13-9-8, dan F6160291-19-14-1-5 memiliki daun yang nyata lebih lebar dibandingkan varietas Batari dan sebanding dengan varietas Bara, Genie, dan Catas.

Karakter tinggi tanaman memilliki pengaruh terhadap pertumbuhan serta produksi tanaman. Tanaman dengan nilai tinggi tanaman dan diameter batang paling tinggi seperti galur F8160291-9-1 menunjukan ciri tanaman yang kokoh (Tabel 2). Beberapa serangan penyakit dapat menular dan terbawa oleh percikan air hujan seperti busuk buah antraknosa dan layu bakteri (Meilin, 2014). Hal ini menjadikan tanaman yang memiliki nilai tinggi dikotomus dan tinggi tanaman paling rendah sangat berpotensi terkena serangan penyakit tersebut. Hal ini serupa dengan yang terjadi di lapangan saat penelitian. Galur F8145381-1-1 merupakan tanaman yang hampir seluruhnya terkena penyakit layu bakteri. Kondisi ini diduga percikan air sumber bakteri dari permukaan bedengan mengenai tanaman sehingga tanaman sangat beresiko terkena serangan penyakit.

Daun berperan sebagai organ utama dalam proses fotosintesis pada tanaman tingkat tinggi. Nilai lebar daun dan panjang daun dapat mempengaruhi jumlah serapan cahaya matahari. Berdasarkan pernyataan Gardner et al. (1985) bahwa tanaman dengan permukaan luar daun yang luas dan datar memungkinkan menyerap cahaya semaksimal 
mungkin.Hal ini dikarenakan daun dengan permukaan luas dan datar dapat meminimalkan jarak yang harus ditempuh $\mathrm{CO}_{2}$ dari permukaan daun ke kloroplas dan memiliki klorofil dalam jumlah banyak sehingga tanaman melakukan proses fotosintesis lebih efektif. Amrullah (2000) mengatakan bahwakarakter panjang dan lebar daun berkolerasi positif dengan jumlah klorofil.

Karakter panjang buah pada galur yang diuji saat penelitian memiliki nilai antara $2.57-5.65 \mathrm{~cm}$. Nilai panjang buah yang terendah adalah galur F8145381-1-1-1-3-1 sedangkan tertinggi pada galur F8160291-3-12-5-4-51-1. Galur F8160291-3-12-5-4-51-1 memiliki buah nyata lebih panjang dibandingkan dengan seluruh varietas pembanding. Sedangkan galur F8145291-115-8-1-1 memiliki buah nyata lebih panjang dibandingkan varietas pembanding Genie dan Catas, selain itu galur F8145291-115-8-1-1 juga sebanding dengan varietas pembanding lainnya (Tabel 3). Genotipe F7145291-14-10-10-4-9, F6145291-14-9-3-12, F61602914-13-9-8, F6145174-9-7-1-5, dan F6160291-19- 4-1-5 memiliki nilai panjang buah sebanding dengan seluruh varietas yang dijadikan pembanding.

Diameter buah pada galur yang diuji memiliki nilai berkisar antara 7.14-9.78 mm. Varietas yang dijadikan pembanding memiliki nilai diameter buah antara 6.897.20 mm. Galur F6145291-14-9-3-12 menampilkan ukuran diameter buah dengan nilai paling tinggi dan nyata lebih besar dibandingkan seluruh varietas pembanding (Tabel 3). Genotipe F7145291-14-10-10-4-9 memiliki buah yang nyata lebih besar dibandingkan varietas Bara dan Catas dan sebanding dengan varietas lainnya.
Karakter jumlah buah pada galur yang diuji memiliki nilai berkisar antara 46.67-213.07 g dan 36.92-165.44 g pada varietas pembanding. Galur uji F8160291-9-4-3-21-1 memiliki nilai jumlah buah $213.07 \mathrm{~g}$ berbeda nyata lebih tinggi dibandingkan seluruh varietas pembanding. Genotipe F7145291-14-10-10-4-9 memiliki jumlah buah yang berbeda nyata lebih tinggi dibandingkan varietas pembanding Bara, Genie, dan Batari namun sebanding dengan varietas Taringe dan Catas. Genotipe F6145291-149-3-12, F6160291-4-13-9-8, F6145174-9-7-1-5, F616029119-14-1-5 memiliki jumlah buah yang berbeda nyata dengan varietas pembanding Batari dan sebanding dengan varietas pembanding Catas, Bara, Taringe dan Genie.

Galur yang diuji memiliki tebal daging buah dengan rerata nilai antara $0.50-0.88 \mathrm{~cm}$, sedangkan pada varietas pembanding tebal daging buah berkisar antara 0.54-0.68 $\mathrm{cm}$ (Tabel 3). Nilai tebal daging buah tertinggi dimiliki oleh galur F6145291-14-9-3-12 sedangkan terendah pada galur F8160291-3-12-5-4-51-1. Galur uji F6145291-14-9-3-12 memiliki daging buah yang nyata lebih tebal dibandingkan seluruh varietas pembanding. Genotipe F8160291-3-12-54-51-1 memiliki karakter daging buah yang nyata lebih tebal dibandingkan varietas pembanding Bara, Genie, dan Catas namun sebanding dengan varietas Taringe dan Batari.

Karakter bobot per buah pada galur yang diuji memiliki rerata nilai antara $0.86-1.77 \mathrm{~g}$ dan pada varietas pembanding memiliki nilai antara 0.82-1.00 g. Galur F8160291-3-12-5-4-51-1 memiliki nilai bobot per buah paling tinggi diantara seluruh galur yang diuji (Tabel 3). Genotipe F8160291-3-12-5-4-51-1 dan F6145291-14-9-

Tabel 2. Nilai rataan karakter vegetatif sepuluh galur yang diuji dan lima varietas pembanding

\begin{tabular}{|c|c|c|c|c|c|}
\hline Genotipe & $\begin{array}{c}\text { Tinggi tanaman } \\
(\mathrm{cm})\end{array}$ & $\begin{array}{c}\text { Tinggi } \\
\text { dikotomus }(\mathrm{cm})\end{array}$ & $\begin{array}{c}\text { Diameter } \\
\text { batang }(\mathrm{cm})\end{array}$ & $\begin{array}{l}\text { Panjang daun } \\
(\mathrm{cm})\end{array}$ & Lebar daun $(\mathrm{cm})$ \\
\hline F6145291-10-7-1-1-1 & $51.70 \mathrm{def}$ & $22.80 \mathrm{bc}$ & $7.91 \mathrm{~b}-\mathrm{f}$ & $6.69 \mathrm{ab}$ & $2.81 \mathrm{a}-\mathrm{d}$ \\
\hline F8160291-9-4-3-2-1-1 & $67.43 \mathrm{a}$ & $23.50 \mathrm{bc}$ & $10.52 \mathrm{a}$ & 5.56 cde & $2.08 \mathrm{ef}$ \\
\hline F8160291-3-12-5-4-51-1 & $51.46 \mathrm{ef}$ & $23.44 \mathrm{bc}$ & $8.99 \mathrm{~b}$ & $5.70 \mathrm{~cd}$ & 2.39 cde \\
\hline F8145291-115-8-1-1 & $62.22 \mathrm{ab}$ & $30.29 \mathrm{a}$ & $8.20 \mathrm{~b}-\mathrm{e}$ & $7.11 \mathrm{a}$ & $2.81 \mathrm{a}-\mathrm{d}$ \\
\hline F8145381-1-1-1-1-3-1 & $32.62 \mathrm{~h}$ & $14.40 \mathrm{e}$ & $7.06 \mathrm{fg}$ & $4.81 \mathrm{de}$ & $1.71 \mathrm{f}$ \\
\hline F7145291-14-10-10-4-9 & $59.57 \mathrm{a}-\mathrm{d}$ & $22.57 \mathrm{bc}$ & $8.88 \mathrm{bc}$ & $7.31 \mathrm{a}$ & $3.17 \mathrm{ab}$ \\
\hline F6145291-14-9-3-12 & $45.08 \mathrm{fg}$ & $17.31 \mathrm{~d}$ & $8.60 \mathrm{bcd}$ & $6.72 \mathrm{ab}$ & $2.64 \mathrm{~b}-\mathrm{e}$ \\
\hline F6160291-4-13-9-8 & $62.87 \mathrm{ab}$ & $23.87 \mathrm{~b}$ & $7.94 \mathrm{~b}-\mathrm{f}$ & $6.68 \mathrm{ab}$ & $3.06 \mathrm{abc}$ \\
\hline F6145174-9-7-1-5 & $51.81 \mathrm{def}$ & $23.10 \mathrm{bc}$ & $8.10 \mathrm{~b}-\mathrm{f}$ & $4.83 \mathrm{de}$ & $2.07 \mathrm{ef}$ \\
\hline F6160291-19-14-1-5 & $61.06 \mathrm{abc}$ & $27.97 \mathrm{a}$ & $8.02 b-f$ & $5.97 \mathrm{bc}$ & $3.04 \mathrm{abc}$ \\
\hline Bara & 48.17 ef & $22.77 \mathrm{bc}$ & $7.54 \mathrm{def}$ & $5.88 \mathrm{bc}$ & $2.84 \mathrm{a}-\mathrm{d}$ \\
\hline Taringe & $55.60 \mathrm{~b}-\mathrm{e}$ & $29.03 \mathrm{a}$ & $7.86 \mathrm{c}-\mathrm{f}$ & $6.77 \mathrm{ab}$ & $3.4 \mathrm{a}$ \\
\hline Batari & $39.17 \mathrm{gh}$ & $20.47 \mathrm{c}$ & $6.40 \mathrm{~g}$ & $4.77 \mathrm{e}$ & $2.31 \mathrm{def}$ \\
\hline Genie & 53.93 cde & $24.33 b$ & $7.43 \mathrm{ef}$ & $5.91 \mathrm{bc}$ & $2.80 \mathrm{a}-\mathrm{d}$ \\
\hline Catas & 47.73 ef & $21.47 \mathrm{bc}$ & $7.52 \mathrm{def}$ & $5.85 \mathrm{bc}$ & $2.55 \mathrm{~b}-\mathrm{e}$ \\
\hline
\end{tabular}

Keterangan : Nilai pada kolom yang sama yang diikuti oleh huruf yang sama menunjukkan tidak berbeda nyata berdasarkan uji DMRT pada taraf $\alpha=5 \%$. 
3-12 memiliki bobot per buah yang nyata lebih tinggi jika dibandingkan dengan seluruh varietas pembanding. Galur uji F8145291-115-8-1-1 bernilai bobot per buah yang nyata lebih tinggi dibandingkan varietas Genie dan Catas, namun sebanding dengan varietas pembanding Bara, Taringe, dan Batari.

Proses pertumbuhan dan perkembangan tanaman seperti ukuran buah dipengaruhi faktor genetik juga lingkungan (Hill, 1975). Faktor genetik pada suatu tanaman dapat kita lihat apabila lingkungan berada pada kondisi yang baik. Kondisi lingkungan yang sesuai memungkinkan organ-organ penghasil sumber makanan (source) bekerja efektif menghasilkan asimilat bagi organ penyimpan seperti buah, biji, dan umbi (Sonnewald and Willmitzer, 1992). Galur F8160291-3-12-5-4-51-1 memiliki fenotipe buah yang sangat panjang karena karakter buah dari galur tersebut seperti cabai merah besar. Sedangkan galur F8160291-312-5-4-51-1 berukuran panjang buah sangat pendek karena galur tersebut berasal dari cabai rawit hias.

Bobot per tanaman hasil analisis menunjukan pada galur yang diuji memiliki nilai antara 43.18-217.62 g sedangkan pada varietas pembanding memiliki nilai bobot per tanaman antara 37.19-144.14 g. Berdasarkan data pada Tabel 7, galur uji F7145291-14-10-10-4-9 dan F81602919-4-3-2-1-1 memiliki bobot per tanaman yang nyata lebih tinggi dibandingkan dengan seluruh varietas pembanding. Galur F8160291-3-12-5-4-51-1, dan F6145291-14-9-3-12 memiliki nilai bobot per tanaman yang nyata lebih tinggi dibandingkan varietas pembanding Bara, Genie, dan Batari, namun sebanding dengan varietas Taringe dan Catas.
Karakter bobot per tanaman pada galur uji F6145291-115-81-1, F6160291-4-13-9-8, F6145174-9-7-1-5, dan F616029119-14-1-5 nyata lebih berat dibandingkan varietas Batari dan sebanding dengan varietas pembanding Bara dan Genie (Tabel 4).

Umur panen ditentukan ketika jumlah tanaman yang siap untuk dipanen telah mencapai minimal 50\% dalam satu bedeng. Seluruh galur uji terhadap varietas pembanding tidak memiliki umur berbunga yang berbeda nyata. Umur berbunga pada galur yang diuji berada pada nilai 39.344.3 HST dan 40.7-43.0 HST pada varaietas pembanding. Karaker umur panen pada galur yang diuji memiliki nilai berkisar antara 74.7-87.0 HST sedangkan umur panen pada varietas pembanding antara 76.33-86.67 HST (Tabel 4). Galur F6145291-10-7-1-1-1, dan F6145291-14-9-312 memiliki umur panen yang sebanding dengan varietas Bara dan umur panen yang nyata lebih cepat dibandingkan varietas pembanding lainnya. Genotipe F8160291-3-12-54-1-1, dan F7145291-14-10-10-4-9 memiliki karakter umur panen yang nyata lebih cepat dibandingkan varietas Genie, Taringe, dan Batari namun sebanding dengan varietas pembanding Catas.

Persen tanaman yang hidup hingga panen ke lima pada galur uji berkisar antara 50\%-87\%, sedangkan pada varietas pembanding berada pada rentang 67\%-83\% (Tabel 4). Galur F8160291-9-4-3-2-1-1 memiliki persen tanaman hidup paling tinggi dibandingkan dengan seluruh varietas pembanding yaitu sebesar $87 \%$. Berdasarkan data pada Tabel 7 galur F7145291-14-10-10-4-9 miliki persen tanaman hidup lebih tinggi dibandingkan varietas Bara namun sebanding

Tabel 3. Nilai rataan karakter komponen daya hasil sepuluh galur yang diuji dan varietas pembanding

\begin{tabular}{|c|c|c|c|c|c|}
\hline Genotipe & $\begin{array}{c}\text { Panjang buah } \\
(\mathrm{cm})\end{array}$ & $\begin{array}{c}\text { Diameter buah } \\
(\mathrm{mm})\end{array}$ & $\begin{array}{c}\text { Bobot per buah } \\
(\mathrm{g})\end{array}$ & Jumlah buah & $\begin{array}{l}\text { Tebal daging buah } \\
(\mathrm{mm})\end{array}$ \\
\hline F6145291-10-7-1-1-1 & $3.49 \mathrm{bcd}$ & $7.77 \mathrm{bc}$ & $0.94 \mathrm{~cd}$ & $111.87 \mathrm{def}$ & $0.66 \mathrm{bcd}$ \\
\hline F8160291-9-4-3-2-1-1 & $3.47 \mathrm{bcd}$ & $7.34 \mathrm{bc}$ & $0.92 \mathrm{~cd}$ & $213.07 \mathrm{a}$ & $0.62 \mathrm{bcd}$ \\
\hline F8160291-3-12-5-4-51-1 & $5.65 \mathrm{a}$ & $7.60 \mathrm{bc}$ & $1.77 \mathrm{a}$ & $103.33 \mathrm{ef}$ & $0.77 \mathrm{ab}$ \\
\hline F8145291-115-8-1-1 & $4.39 \mathrm{~b}$ & $7.73 \mathrm{bc}$ & $1.21 \mathrm{bc}$ & $92.21 \mathrm{f}$ & $0.50 \mathrm{~d}$ \\
\hline F8145381-1-1-1-1-3-1 & $2.57 \mathrm{~d}$ & $7.67 \mathrm{bc}$ & $0.93 \mathrm{~cd}$ & $46.47 \mathrm{~g}$ & $0.58 \mathrm{~cd}$ \\
\hline F7145291-14-10-10-4-9 & $3.69 \mathrm{bc}$ & $7.97 \mathrm{~b}$ & $1.09 \mathrm{~cd}$ & $199.10 \mathrm{ab}$ & $0.69 \mathrm{bc}$ \\
\hline F6145291-14-9-3-12 & $3.63 \mathrm{bc}$ & $9.78 \mathrm{a}$ & $1.48 \mathrm{ab}$ & $120.85 \mathrm{c}-\mathrm{f}$ & $0.88 \mathrm{a}$ \\
\hline F6160291-4-13-9-8 & $3.96 \mathrm{bc}$ & $7.14 \mathrm{bc}$ & $0.97 \mathrm{~cd}$ & $155.18 \mathrm{bcd}$ & $0.52 \mathrm{~cd}$ \\
\hline F6145174-9-7-1-5 & $3.62 \mathrm{bc}$ & $7.66 \mathrm{bc}$ & $1.10 \mathrm{~cd}$ & $121.96 \mathrm{c}-\mathrm{f}$ & $0.65 \mathrm{bcd}$ \\
\hline F6160291-19-14-1-5 & $3.55 \mathrm{bc}$ & $7.58 \mathrm{bc}$ & $0.86 \mathrm{~cd}$ & $131.97 \mathrm{c}-\mathrm{f}$ & $0.59 \mathrm{bcd}$ \\
\hline Bara & $3.56 \mathrm{bc}$ & $6.89 \mathrm{c}$ & $0.88 \mathrm{~cd}$ & $131.50 \mathrm{c}-\mathrm{f}$ & $0.55 \mathrm{~cd}$ \\
\hline Taringe & $3.67 \mathrm{bc}$ & $7.08 \mathrm{bc}$ & $0.87 \mathrm{~cd}$ & $165.44 \mathrm{bc}$ & $0.59 \mathrm{bcd}$ \\
\hline Batari & $3.62 \mathrm{bc}$ & $7.21 \mathrm{bc}$ & $1.00 \mathrm{~cd}$ & $36.92 \mathrm{~g}$ & $0.68 \mathrm{bcd}$ \\
\hline Genie & $3.12 \mathrm{~cd}$ & $7.17 \mathrm{bc}$ & $0.82 \mathrm{~d}$ & 149.15 cde & $0.57 \mathrm{~cd}$ \\
\hline Catas & $3.33 \mathrm{~cd}$ & $6.95 \mathrm{c}$ & $0.84 \mathrm{~d}$ & $156.86 \mathrm{bcd}$ & $0.54 \mathrm{~cd}$ \\
\hline
\end{tabular}

Keterangan : Nilai pada kolom yang sama yang diikuti oleh huruf yang sama menunjukkan tidak berbeda nyata berdasarkan uji DMRT pada taraf $\alpha=5 \%$. 
dengan varietas Genie sebesar 83\%. Galur F8145318-1-11-1-3-1 dan varietas Batari memiliki nilai bobot pertanaman yang sangat rendah. Ketika di lapangan galur dan varietas tersebut terkena penyakit layu bakteri yang menyebabkan hampir seluruh tanaman layu serta buah muda gugur. Hal ini disebabkan karakter tinggi tanaman dan tinggi dikotomus pada galur F8145318-1-1-1-1-3-1 bernilai rendah sehingga meningkatkan resiko tanaman terserangan penyakit. Bobot per buah dan bobot per tanaman merupakan karakter utama yang dipilih dalam proses pemuliaan tanaman. Hasil penelitian Anggraini (2006) dan Kusmanto (2014) bobot per buah menjadi kriteria penting dalam menentukan peforma daya hasil suatu tanaman.

Berdasarkan data nilai bobot per tanaman, produktivitas galur F7145291-14-10-10-4-9 dan F8160291-9-4-3-2-1-1 lebih tinggi dibandingkan seluruh varietas pembanding (Tabel 4). Jarak tanam yang digunakan adalah $50 \mathrm{~cm}$ x 50 $\mathrm{cm}$ dengan lebar bedengan $1 \mathrm{~m}$ maka popolasi per hektar sejumlah 26,670 tanaman. Asumsi jika tanaman yang mampu berproduksi dengan baik sebanyak $80 \%$ maka galur F7145291-14-10-10-4-9 memiliki produktivitas 4.64 ton ha $^{-1}$ dan galur F8160291-9-4-3-2-1-1 memiliki produktivitas 4.20 ton ha-1 . Berdasarkan bobot per tanaman varietas Bara dan Genie memiliki produktivitas sebesar 2.47 ton $\mathrm{ha}^{-1}$ dan 2.62 ton $\mathrm{ha}^{-1}$.

Galur F7145291-14-10-10-4-9 pada penelitian sebelumnya memiliki produktivitas lebih tinggi yaitu 5.96 ton ha $^{-1}$ (Silaban, 2018). Menurut data Kementan (2017) bahwa varietas Bara memiliki deskripsi potensi produktivitas 10 ton $\mathrm{ha}^{-1}$ dan varietas Genie mempunyai potensi hasil 13 ton ha ${ }^{-1}$. Hal ini menjelaskan bahwa produktivitas galur F714529114-10-10-4-9, varietas pembanding Bara dan Genie tidak berproduksi secara baik. Daya hasil cabai rawit yang rendah dapat disebabkan tingginya curah hujan ketika penelitian yaitu $280 \mathrm{~mm} \mathrm{bulan}^{-1}$. Tanaman cabai rawit menghendaki kondisi curah hujan 50-105 mm bulan ${ }^{-1}$ (Setiadi, 2005). Kondisi curah hujan yang tinggi menyebabkan tanaman lebih mudah terserang penyakit karena penyakit dapat berkembang dengan mudah (Prasath et al., 2007).

Karakter umur panen yang diinginkan dalam pemuliaan tanaman yaitu galur yang memiliki umur panen yang cepat. Sujiprihati et al. (2007) mengatakan karakter umur panen memiliki nilai korelasi negatif terhadap karakater daya hasil sehingga tanaman yang bernilai kecil pada karakter umur berbunga dan panen dibutuhkan dalam pemuliaan tanaman.

\section{Korelasi antar Karakter}

Korelasi merupakan indikator keeratan hubungan antar dua karakter atau lebih. Hubungan keeratan antar karakter ditunjukan oleh nilai koefisien korelasi yang memiliki rentang nilai antara -1 dan +1 . Koefisien korelasi yang memiliki nilai semakin mendekati -1 atau +1 maka hubungan antar karakter tersebut semakin erat, sedangkan karakter yang memiliki nilai koefisien korelasi mendekati 0 maka hubungan semakin tidak erat antar karakter yang dianalisis (Gomez dan Gomez, 1995).

Analisis korelasi menunjukan bahwa karakter yang berkolerasi positif terhadap bobot per buah adalah diameter batang, diameter buah, dan panjang buah. Hal ini menjelaskan semakin tinggi nilai karakter diameter batang, diameter buah, dan panjang buah maka nilai bobot per buah juga semakin tinggi. Karakter panjang buah memiliki nilai koefisien korelasi paling tinggi terhadap bobot per buah

Tabel 4. Nilai rataan karakter bobot per tanaman,persentanamanhidup, produktivitas, dan umur panen galur yang diuji dan varietas pembanding

\begin{tabular}{lcccc}
\hline \multicolumn{1}{c}{ Genotipe } & Bobot per tanaman $(\mathrm{g})$ & Tanaman hidup (\%) & Produktivitas (ton/ha) & Umur panen (HST) \\
\hline F6145291-10-7-1-1-1 & $104.83 \mathrm{~d}$ & 73 & 2.05 & $76.7 \mathrm{e}$ \\
F8160291-9-4-3-2-1-1 & $196.24 \mathrm{ab}$ & 87 & 4.54 & $87.0 \mathrm{a}$ \\
F8160291-3-12-5-4-51-1 & $182.55 \mathrm{abc}$ & 77 & 3.73 & $81.0 \mathrm{~d}$ \\
F8145291-115-8-1-1 & $111.20 \mathrm{~d}$ & 57 & 1.68 & $87.0 \mathrm{a}$ \\
F8145381-1-1-1-1-3-1 & $43.18 \mathrm{e}$ & 80 & 0.92 & $85.7 \mathrm{ab}$ \\
F7145291-14-10-10-4-9 & $217.62 \mathrm{a}$ & 83 & 3.84 & $80.7 \mathrm{~d}$ \\
F6145291-14-9-3-12 & $178.86 \mathrm{abc}$ & 70 & 2.95 & $74.7 \mathrm{e}$ \\
F6160291-4-13-9-8 & $151.00 \mathrm{bcd}$ & 73 & 1.79 & $84.0 \mathrm{bc}$ \\
F6145174-9-7-1-5 & $134.32 \mathrm{~cd}$ & 50 & 1.72 & $81.7 \mathrm{~cd}$ \\
F6160291-19-14-1-5 & $113.67 \mathrm{~d}$ & 57 & 2.37 & $85.7 \mathrm{ab}$ \\
Bara & $115.71 \mathrm{~d}$ & 77 & 2.56 & $76.3 \mathrm{e}$ \\
Taringe & $144.14 \mathrm{~cd}$ & 67 & 0.79 & $85.7 \mathrm{ab}$ \\
Batari & $37.19 \mathrm{e}$ & 80 & 2.73 & $86.7 \mathrm{a}$ \\
Genie & $122.81 \mathrm{~d}$ & 83 & 2.82 & $83.7 \mathrm{bc}$ \\
Catas & $132.21 \mathrm{~cd}$ & 80 & $82.0 \mathrm{~cd}$ \\
\hline
\end{tabular}

Keterangan : Nilai pada kolom yang sama yang diikuti oleh huruf yang sama menunjukkan tidak berbeda nyata berdasarkan uji DMRT pada taraf $\alpha=5 \%$ 
Tabel 5. Koefisien nilai korelasi antar karakter kuantitatif pada 10 galur uji dan varietas pembanding cabai rawit

\begin{tabular}{lcccccccccc}
\hline & TT & TD & DB & PD & LD & PB & DBU & BPB & BPT & JBU \\
\hline TT & 1 & & & & & & & & & \\
TD & $0.69^{* *}$ & 1 & & & & & & & \\
DB & $0.59^{* *}$ & $0.18^{\text {tn }}$ & 1 & & & & & & \\
PD & $0.48^{* *}$ & $0.38^{*}$ & $0.31^{*}$ & 1 & & & & & \\
LD & $0.47^{* *}$ & $0.55^{* *}$ & $0.04^{\text {tn }}$ & $0.60^{* *}$ & 1 & & & & \\
PB & $0.34^{*}$ & $0.35^{*}$ & $0.31^{*}$ & $0.18^{\text {th }}$ & $0.17^{\text {tn }}$ & 1 & & & \\
DBU & $-0.12^{\text {tn }}$ & $-0.32^{*}$ & $0.29^{\text {tn }}$ & $0.21^{\text {tn }}$ & $0.00^{\text {tn }}$ & $0.10^{\text {tn }}$ & 1 & & \\
BPB & $0.04^{\text {tn }}$ & $-0.09^{\text {tn }}$ & $0.34^{*}$ & $0.14^{\text {th }}$ & $-0.09^{\text {tn }}$ & $0.79^{* *}$ & $0.47^{* *}$ & 1 & \\
BPT & $0.56^{* *}$ & $0.20^{\text {tn }}$ & $0.80^{* *}$ & $0.47^{* *}$ & $0.35^{*}$ & $0.36^{*}$ & $0.28^{\text {tn }}$ & $0.32^{*}$ & $1.00^{\text {tn }}$ & \\
JBU & $0.66^{* *}$ & $0.32^{*}$ & $0.67^{* *}$ & $0.42^{* *}$ & $0.45^{* *}$ & $0.04^{\text {th }}$ & $-0.03^{\text {tn }}$ & $-0.14^{\text {tn }}$ & $0.84^{* *}$ & 1 \\
\hline
\end{tabular}

Keterangan : $*$ = berkorelasinyata pada taraf $5 \% * *=$ berkorelasinyata pada taraf $1 \%$, th $=$ tidakberkorelasinyata pada taraf $5 \%$, TT $=$ tinggitanaman; $\mathrm{TD}=$ tinggidikotomus; $\mathrm{DB}=$ diameter batang; $\mathrm{PD}=$ panjangdaun; $\mathrm{LD}=$ lebardaun; $\mathrm{PB}=$ panjang buah; $\mathrm{DBU}=$ diameter buah; $\mathrm{BPB}=$ bobot per buah; $\mathrm{BPT}=$ bobot per tanaman; JBU $=$ jumlah buah

yaitu 0.79 (Tabel 5). Karakter bobot per tanaman berkolerasi positif terhadap karakter tinggi tanaman, diameter batang, panjang daun, lebar daun, panjang buah. Hal ini menunjukan bahwa semakin tinggi nilai dari karakter-karakter tersebut maka nilai bobot per tanaman semakin tinggi. Karakter diameter batang memiliki nilai koefisien korelasi tertinggi terhadap bobot buah per tanaman yaitu 0.80 .

Hasil analisis korelasi menunjukan jumlah buah berkolerasi positif terhadap karakter tinggi tanaman, tinggi dikotomus, diameter batang, panjang daun, lebar daun, dan bobot per tanaman. Karakter dengan nilai koefisien korelasi tertinggi terhadap jumlah buah yaitu bobot per tanaman. Hal ini menjelaskan jika semakin banyak jumlah buah pada suatu tanaman maka nilai bobot per tanaman akan bertambah tinggi (Tabel 5).Karakter tinggi tanaman memiliki pengaruh terhadap bobot per tanaman yang dihasilkan.Tanaman yang memiliki sifat tinggi tanaman yang tinggi mampu membentuk percabangan yang banyak sehingga akan terbentuk bunga dan buah dari setiap percabangan dalam jumlah yang banyak (Sujitno dan Dianawati, 2015). Hasil penelitian sebelumnya juga mengatakan bahwa bobot buah per tanaman berkolerasi secara positif dengan karakter tinggi tanaman, jumlah buah, panjang buah, dan diameter buah (Amrullah, 2000; Sujitno dan Dianawati, 2015; Sidiq, 2016).

\section{KESIMPULAN}

Terdapat galur cabai rawit IPB menunjukan penampilan karakter yang lebih baik dibandingkan varietas pembanding. Galur F8160291-9-4-3-2-1-1 dan F6145291115-8-1-1 memiliki karakter pertumbuhan tanaman lebih tinggi dibandingkan dengan seluruh varietas pembanding. Karakter buah pada galur F8160291-3-12-5-4-51-1 dan F6145291-14-9-3-12 memiliki nilai bobot buah dan panjang buah yang tinggi dibandingkan dengan seluruh varietas pembanding. Genotipe F7145291-14-10-10-4-9, F81602919-4-3-2-1-1, F8160291-3-12-5-4-51-1, dan F6145291-14-93-12 memiliki karakter bobot per tanaman yang lebih tinggi dibandingkan varietas pembanding. Berdasarkan analisis kolerasi, karakter tinggi tanaman, jumlah buah dan bobot per buah sangat penting untuk menetukan peforma daya hasil suatu tanaman dan menjadi acuan untuk melakukan seleksi.

\section{DAFTAR PUSTAKA}

Amrullah. 2000. Tingkat kandungan klorofil daun dan kontribusinya serta pengaruh pemupukan NPKMg dan pemberian metanol terhadap kandungan klorofil, pertumbuhan dan produktivitas tanaman cabai merah (Capsicum annuum L.). Tesis. Program Pascasarjana IPB, Bogor.

Anggraini, P. 2006. Keragaan sembilan genotipe cabai merah (Capsicum annuum L.) generasi keempat hasil persilangan three way cross. Skripsi. Institut Pertanian Bogor.

Bank Indonesia. Release Note Inflasi Oktober 2016. http:// www.bi.go.id [17 Desember 2017].

[BPS] Badan Pusat Statistik. 2015. Produksicabaibesar, cabairawit, dan bawangmerah. https://www.bps. go.id [3 Oktober 2017].

[BPS] Badan Pusat Statistik. 2016. Luas panen, dan produktivitas sayuran di indonesia. http://www. pertanian.go.id [26 November 2017].

Direktorat Perbenihan Hortikultura Kementerian Pertanian. 2017. Database Varietas Terdaftar Hortikultura. http://varietas.net/dbvarietas/ [17 Desember 2017]. 
Gardner, F.P., R.B. Pearce, R.I. Mitchell. 1985. Physiology of Crop Plant. Iowa State University Press, Ames.

Gomez, K.A., A.A. Gomez, 1995. Prosedur Statistik untuk Penelitian Pertanian. Diterjemahkan oleh: E. Sjamsuddin dan J.S. Baharsjah. UIPress, Jakarta.

[IPGRI] International Plant Genetic Resources Institute. 1995. Descriptor for Capsicum (Capsicum spp.). Italy (IT): IPGRI, AVRDC, CATIE.

Kouassi, C.K., R. Koffi-nevry, L.Y. Guillaume. 2012. Profiles of bioactive compounds of some pepper fruit (Capsicum L.) varieties grown in Cote d'ivoire. Innovative Romanian Food Biotechnol. 11:23-31.

Kusmanto. 2014. Uji daya hasil sepuluh galur cabai (Capsicum annuum L.) bersari bebas yang potensial sebagai varietas unggul. Skripsi. Institut Pertanian Bogor.

Meilin, A. 2014. Hama dan Penyakit pada Tanaman Cabai Serta Pengendaliannya. Balai Pengkajian Teknologi Pertanian. Jambi.

Poerwanto, R.., D.S. Anas. 2014. Teknologi Hortikultura Seri 1 Hortikultura Tropika. IPB Press. Bogor.

Prasath, D., V. Ponnuswami, V. Muralidharan. 2007. Source of resistance to anthracnose (Colletotrichum capsici) disease in Capsicum spesies. Indian J Agric Sci. 77(7):473-474.

[Pusdatin Kementan] Pusat Data dan Sistem Informasi Kementerian Pertanian. 2016. Outlook komoditas pertanian sub sektor hortikultura. Kementerian Pertanian.

Setiadi. 2005. Bertanam Cabai. Penebar Swadaya. Bogor.

Sidiq, A.R.J. 2016. Pendugaan parameter genetika dan seleksi karakter kuantitatif cabai rawit (Capsicum annuum L.) popoulasi F3. Skripsi. Institut Pertanian Bogor.

Silaban, Y.W. 2018. Uji daya hasil pendahuluan cabai rawit (Capsicum annuum L.) generasi F5. Skripsi. Institut Pertanian Bogor.

Sonnewald, U., L. Willmitzer. 1992. Moluculer approaches to sink-source interactions. Plant Physiol. 99:12671270 .

Sujiprihati, S., R. Yunianti, M. Syukur, Undang. 2007. Pendugaan nilai heterosis dan daya gabung beberapa komponen hasil pada persilangan dialel penuhenam genotipe cabai (Capsicum annuum L.). Bul. Agron. 35:28-35.

Sujitno, E., M. Dianawati. 2015. Produksi panen berbagai varietas unggul baru cabai rawit (Capsicum frutescens) di lahan kering Kabupaten Garut, Jawa Barat. Dalam Setyawan A.D., Sugiyarto, A. Pitoyo, U.E. Hernawan dan A. Widiastuti. (Eds). Manajemen Biodiversitas dalam Melindungi, Mempertahankan dan Memperkaya Sumber daya Genetik dan Pemanfaatannya. Seminar Nasional Masyarakat Biodiversitas Indonesia; Yogyakarta, 21 Maret 2015.

Syukur, M., S. Sujiprihati, R. Yunianti, K. Nida. 2010. Pendugaan komponen ragam, heritabilitas dan korelasi untuk menentukan kriteria seleksi cabai (Capsicum annuum L.) populasi F5. J. Hort. Indonesia. 1:74-80.

Syukur, M., S. Sujiprihati, R. Yunianti. 2015. Teknik Pemuliaan Tanaman. Penebar Swadaya. Bogor.

Tsurayya, S., L. Kartika. 2015. Kelembagaan dan strategi peningkatan daya saing komoditas cabai kabupaten Garut. J Manajemen dan Agribisnis. 12(1):1-13.

Wattimena, G.A. 2011. Bioteknologi Dalam Pemuliaan Tanaman. Pendahuluan. IPB Press. Bogor. 